\title{
DEGRADATION OF SEWAGE SLUDGE COMPOST DISPOSED ON THE SOIL
}

Doi:http://dx.doi.org/10.1590/1809-4430-Eng.Agric.v36n5p822-829/2016

\section{ISABELA C. C. DINIZ ${ }^{1 *}$, ANTONIO T. MATOS ${ }^{2}$, ALISSON C. BORGES ${ }^{1}$, JULIANA M. G. L. AQUINO ${ }^{3}$, MATEUS P. MATOS ${ }^{4}$}

\begin{abstract}
This study aimed to monitor degradation of compost from undigested sewage sludge disposed on soil surface or incorporated it. The sewage sludge was blended with wood sawdust during a 90-day composting to achieve a $\mathrm{C} / \mathrm{N}$ ratio of 9 . Each waste was dosed based on its total content of nitrogen and on an annual dose of $500 \mathrm{~kg} \mathrm{ha}^{-1}$, which is broadly recommended for forage fertilization. After incorporation and surface applied (five replicates each), waste mineralization was monitored for 131 days by samplings taken from both conditions for further analyses. The samples were measured for total organic carbon (TOC); easily oxidizable carbon (OOC); total nitrogen $(\mathrm{TN})$; ammonia and nitric nitrogen, and from them the total organic nitrogen $(\mathrm{ON})$; volatile solids; and water content. The findings pointed to a decrease in TOC, OOC and ON contents throughout monitoring, regardless of disposal method, however, most remarkable whether incorporated to the soil, computing mineralization rates above $87 \%$.
\end{abstract}

KEY WORDS: composting, undigested sewage sludge, mineralization fraction.

\section{INTRODUCTION}

Population growth coupled with urbanization, industrialization and economic development are indicative and the cause of increasing waste generation (HECK et al., 2013). Sewage sludge has been gaining more and more prominence in Brazil and worldwide, due to the large amounts generated in treatment plants. Such waste has high content of organic matter and nutrients, among other chemical elements (KUMMER, 2013), and should have a proper final disposal before its hazardous impacts on the environment.

As a final destination, the sludge incorporation in soil is the alternative with greatest potential because this material improves the chemical, physical and biological properties of soils, reducing costs in the restoration of road embankments (FERRER et al., 2011) and agricultural production process. Agriculture has long recognized the benefits of waste materials as a nutrient source and as an amendment to improve the physical and chemical properties of soils (ALVARENGA et al., 2015; SINGH and AGRAWAL, 2008).

In Brazil, a large amount of sewage sludge has still been discarded onto landfills, which goes against the National Solid Waste Policy that provides lesser disposal of solid wet wastes into such areas (GODOY, 2013). Sewage sludge has to be sanitized and stabilized prior to final disposal, since "fresh" mud has high rot potential, releasing of odors and high concentration of pathogenic microorganisms. Likewise, before agricultural use, a pretreatment is required such as solarization, composting, vermicomposting and liming (NASCIMENTO et al., 2014). Composting is a nutrient recycling system and one way speeding up organic matter decomposition, as it would be naturally.. It is an aerobic biological process, in which mesophilic or thermophilic microorganisms stabilize biodegradable solids. During organic material biodegradation, temperatures rise within a range of 60 to $65{ }^{\circ} \mathrm{C}$ in the early days, killing pathogenic microorganisms found in the biosolid. A function of the high temperatures achieved, composting is not only a stabilization technique but also a cleaning process and one of the most effective means of recycling organic waste for agricultural purposes.

\footnotetext{
${ }^{1}$ Universidade Federal de Viçosa/Viçosa - MG, Brasil.

${ }^{2}$ Universidade Federal de Minas Gerais/Belo Horizonte - MG, Brasil.

${ }^{3}$ Univiçosa/Viçosa - MG,Brasil.

${ }^{4}$ Universidade Federal de Lavras/Lavras - MG, Brasil.

*Corresponding author. E-mail: belcorradi@gmail.com

Received in: 1-12-2015

Accepted in: 5-23-2016
} 
After being discharged onto the soil, sewage compounds undergo oxidation to form carbon dioxide and water, leaving only difficult-to-degrade materials like humic substances. These components provide improvements in quality and productive potential of agricultural land, and major agronomic benefits.

Given the above, our research aimed at evaluating and monitoring degradation of organic material from undigested sewage sludge, after composting and under field conditions, comparing surface application and incorporation to the soil.

\section{MATERIAL AND METHODS}

The experiment was carried out at the Experimental Unit for Urban Waste Treatment of the Department of Agricultural Engineering, Federal University of Viçosa (DEA/ UFV), in Viçosa, Minas Gerais state, Brazil. The local geographical coordinates are $20^{\circ} 45^{\prime} 14^{\prime \prime} \mathrm{S}$ latitude and $42^{\circ} 52^{\prime}$ $53 " \mathrm{~W}$ longitude, and at an average altitude of $650 \mathrm{~m}$.

The sewage sludge was collected from the Sewage Treatment Plant of Arrudas - STP Arrudas - located in the city of Belo Horizonte, which is managed by the Sanitation Company of Minas

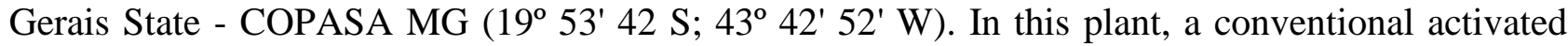
sludge model (ASM) treats the settled sewage, withdrawing sludge samples from a secondary segmentation tank, which is considered undigested. The samples were placed on a drying bed for 35 days for volume reduction, thereby facilitating transportation.

Since it has great availability in local market, sawdust was blended to the sludge, acting as "structuring element", providing thus adequate porosity to the mixture. This residue was purchased from a lumber shop in town, consisting of wood shavings from angelim (Vatairea heteroptera Ducke); it is widely used in wooden roof structures, mileposts, doors, windows, floors, and others in building sector.

The contents of total nitrogen $\left(\mathrm{N}_{\mathrm{T}}\right)$ and total organic carbon (TOC) were measured in samples of sewage sludge from STP Arrudas and of sawdust by the modified-Kjeldahl and the WalkleyBlack methods, respectively (MATOS, 2015). The water content of the material was also quantificated to enable expressing each constituent with reference to its dry weight (Table 1).

TABLE 1. Characterization of the composting wastes by weight in dry matter, and respective water contents.

\begin{tabular}{lccc}
\hline Material & TN & TOC & MC $_{\mathbf{w}}$ \\
\cline { 2 - 4 } & \multicolumn{1}{c}{$----------\mathrm{g} \mathrm{kg}^{-1}---------$} & $\mathrm{dag} \mathrm{kg}^{-1}$ \\
\hline Sewage sludge & 66.63 & 382.75 & 90.25 \\
Sawdust & 1.63 & 574.56 & 11.45 \\
\hline
\end{tabular}

Wherein, $\mathrm{N}_{\mathrm{T}}$ - total nitrogen; TOC - total organic carbon and $\mathrm{MC}_{\mathrm{W}}$ - moisture on the wet basis.

Given these data, calculations were made for sawdust dry matter to be mixed with the sludge. Even though the initial $\mathrm{C} / \mathrm{N}$ ratio of the mixture should be between $25 / 1$ and 35/1, a lower relation was used $(\mathrm{C} / \mathrm{N}=9)$, which, at the same time, is enough for sawdust to absorb water excess from sludge. Composting was carried out by Windrow method, mixing $4.25 \mathrm{~kg}$ sawdust into $103.5 \mathrm{~kg}$ fresh sludge. The material was inverted every 3 days with the aid of a gardening shovel for 90 days. Hereupon, the material was allowed to stand until assembly of the experiment.

Soil chemical and physical analyzes were performed before incorporating and/ or laying of the compost. Chemical characterization consisted of quantifying TOC from volatile solids, OOC by the Walkley-Black method and TN by the modified Kjeldahl method. Additionally, quantifications of the amounts of phosphorus $(\mathrm{P})$, potassium $(\mathrm{K})$ and sodium $(\mathrm{Na})$ by spectrophotometry; $\mathrm{Ca}+\mathrm{Mg}$, $\mathrm{Al}^{3+}$ and $\mathrm{H}+\mathrm{Al}$ by titrimetric methods; in addition to the physical and chemical variables as $\mathrm{pH}$ and electrical conductivity by potentiometry. Physical characterization was made by granulometric analysis carried by the pipette method. 
Similarly, sewage sludge was chemically and physically analyzed, determining $\mathrm{pH}$, water content, organic carbon, $\mathrm{N}_{\mathrm{T}}$, ammonia nitrogen $\left(\mathrm{N} \_\mathrm{NH}_{3}\right)$, nitrogen nitrate $\left(\mathrm{N}_{-} \mathrm{NO}_{3}{ }^{-}\right), \mathrm{P}, \mathrm{K}, \mathrm{Ca}, \mathrm{Mg}$, $\mathrm{S}, \mathrm{Na}$, by the same methods above cited. In addition, total solids (TS), total volatile solids (TVS) and total fixed solids (TFS) (MATOS, 2015).

The analyses were performed at the Laboratory of Soils and Solid Wastes at the Department of Agricultural Engineering of the Federal University of Viçosa. Tables 2 and 3 show characterizations of the soil and the sludge used in this experiment, respectively.

TABLE 2. Soil physical and chemical characterizations.

\begin{tabular}{|c|c|c|}
\hline Variable & Unit & Fresh matter \\
\hline$\overline{\mathrm{TN}}$ & $\left(\mathrm{g} \mathrm{kg}^{-1}\right)$ & 1.03 \\
\hline OOC & $\left(\operatorname{dag} \mathrm{kg}^{-1}\right)$ & 0.88 \\
\hline TOC & $\left(\right.$ dag kg $\left.{ }^{-1}\right)$ & 1.06 \\
\hline O.M. & $\left(\right.$ dag kg $\left.{ }^{-1}\right)$ & 1.82 \\
\hline $\mathrm{pH}$ & & 5.52 \\
\hline $\mathrm{EC}$ & $\left(\mu \mathrm{S} \mathrm{cm}^{-1}\right)$ & 107.08 \\
\hline $\mathrm{K}$ & $\left(\mathrm{mg} \mathrm{dm}^{-3}\right)$ & 57.2 \\
\hline $\mathrm{Na}$ & $\left(\mathrm{mg} \mathrm{dm} \mathrm{m}^{-3}\right)$ & $<0.01$ \\
\hline $\mathrm{Ca}+\mathrm{Mg}$ & $\left(\mathrm{cmol}_{\mathrm{c}} \mathrm{dm}^{-3}\right)$ & 2.86 \\
\hline P-avai & $\left(\mathrm{mg} \mathrm{dm}^{-3}\right)$ & 52.58 \\
\hline $\mathrm{Al}^{3+}$ & $\left(\mathrm{cmol}_{\mathrm{c}} \mathrm{dm}^{-3}\right)$ & 0.07 \\
\hline $\mathrm{H}+\mathrm{Al}$ & $\left(\mathrm{cmol}_{\mathrm{c}} \mathrm{dm}^{-3}\right)$ & 7.41 \\
\hline Clay & $($ dag kg-1) & 43.0 \\
\hline Silt & $($ dag kg-1 $)$ & 12.0 \\
\hline Sand & $\left(\right.$ dag kg $\left.{ }^{-1}\right)$ & 45.0 \\
\hline Specific weight & $\left(\mathrm{g} \mathrm{cm}^{-3}\right)$ & 1.07 \\
\hline
\end{tabular}

As shown in Table 2, the soil can be characterized as dystrophic due to the concentrations of nutrients; therefore, fertilization is required. This way, the addition of the organic compound produced from sewage sludge should be made considering its chemical characteristics as shown in Table 3.

TABLE 3. Compost physical and chemical characterizations.

\begin{tabular}{|c|c|c|c|c|}
\hline Variable $^{(1)}$ & Unit & & ost & \\
\hline$\overline{\mathrm{OOC}^{*} *}$ & dag $\mathrm{kg}^{-1}$ & 25.85 & \pm & 1.84 \\
\hline $\mathrm{pH}$ & - & 6.66 & \pm & 0.03 \\
\hline $\mathrm{TOC}_{(\mathrm{d})} * *$ & $\mathrm{~g} \mathrm{~kg}^{-1}$ & 435.63 & \pm & 3.57 \\
\hline $\mathrm{TN}^{* *} *$ & $\mathrm{~g} \mathrm{~kg}^{-1}$ & 40.11 & \pm & 3.55 \\
\hline $\mathrm{N} \_\mathrm{NO}_{3}{ }^{-* *}$ & $\mathrm{mg} \mathrm{kg}^{-1}$ & 17.23 & \pm & 7.85 \\
\hline $\mathrm{N} \_\mathrm{NH}_{3} * *$ & $\mathrm{~g} \mathrm{~kg}^{-1}$ & 12.76 & \pm & 1.13 \\
\hline $\mathrm{C} / \mathrm{N}^{* *}$ & - & 10.9 & & \\
\hline $\mathrm{Na}^{* *}$ & $\mathrm{~g} \mathrm{~kg}^{-1}$ & 12.32 & \pm & 0.79 \\
\hline $\mathrm{K}^{* *}$ & $\mathrm{~g} \mathrm{~kg}^{-1}$ & 4.26 & \pm & 0.50 \\
\hline $\mathrm{P}^{* *}$ & $\mathrm{~g} \mathrm{~kg}^{-1}$ & 15.26 & \pm & 0.30 \\
\hline TS* & $\mathrm{g} \mathrm{kg}^{-1}$ & 978.48 & \pm & 1.71 \\
\hline TFS** & $\mathrm{g} \mathrm{kg}^{-1}$ & 248.98 & \pm & 6.15 \\
\hline TVS** & $\mathrm{g} \mathrm{kg}^{-1}$ & 751.02 & \pm & 6.15 \\
\hline $\mathrm{MC}_{\mathrm{w}} *$ & dag $\mathrm{kg}^{-1}$ & 5.73 & \pm & 6.08 \\
\hline Specific weight* & $\mathrm{kg} \mathrm{dm}^{-3}$ & 0.35 & & \\
\hline
\end{tabular}


The amount of compost to be applied to the soil was calculated based on the concentration of TN from the waste. The TN established dose was of $500 \mathrm{~kg} \mathrm{ha}^{-1} \mathrm{year}^{-1}$, amount considered suitable for fertilization of forage grasses. Hence, an equivalent of $3.5 \mathrm{~g}$ of $\mathrm{TN}$ was applied per pot, corresponding to $13.3 \mathrm{Mg}$ of composted sludge (C) per hectare $\left(93 \mathrm{~g} \mathrm{pot}^{-1}\right)$. The equivalent added amount per area was calculated based on a root catchment depth of $20 \mathrm{~cm}$ (depth within most roots reach) and soil bulk density of $1.0 \mathrm{~kg} \mathrm{dm}^{-3}$, comprising a mass of 2,000,000 kg of soil by hectare.

According to criteria established by the Brazilian Society of Soil Science, the soil of the area is classified as typical Latosolic Dystrophic Haplic Cambisol - CXbd (Inceptisol). The tests started on the first week of October 2013, ending on the first week of February 2014, i.e. making a total of 131 days monitoring. The soil in the experimental area was removed forming pits, into which plastic pots were placed. These vessels had been perforated at the bottom and sides to allow continued condition, providing contact of the pot contents with the surrounding soil. Such condition would minimize restrictions on movement of solutes between both environments (pot interior and soil around). Soil from pit openings were used to fill the pots, where the compost was either uniformly incorporated to the soil or laid superficially, without embedding.

The experiment was set in three replicates for each treatment (incorporation and laying) plus a control, where sewage sludge compost was not applied.

Samples were collected fortnightly during the first month, and monthly in the following months, totaling thus six samples throughout the 131 days. Using a gardening shovel, samples were withdrew from random points in the pots where compost was incorporated and also from those without the addition. In plots where the compost was laid on the soil surface, samples were removed from the 3-cm top layer. Therefore, it was obtained soil samples (control), soil + compound (incorporated and the last three samples of surface laying) and compound (surface laying) in the first three samples. These samples were forwarded to the Laboratory of Soil and Solid Waste of the same university (DEA/UFV) for analyses of the contents of TOC, OOC, water content $\left(\mathrm{MC}_{\mathrm{w}}\right), \mathrm{TN}$, N_NH 3 and $\mathrm{N}_{-} \mathrm{NO}_{3}{ }^{-}$, following method described by MATOS (2015).

Based on the values from laboratory, organic $\mathrm{C}$ and $\mathrm{N}$ mineralization fractions were estimated to field conditions $\left(\mathrm{MF}_{f c}\right)$ using the eqs. (1), (2) and (3), which compute initial and final concentrations of carbon and nitrogen.

$$
\begin{aligned}
& \text { MFTOC }_{f c}=\left(\text { TOC }_{(\mathrm{i})}-\mathrm{TOC}_{(\mathrm{f})}\right) \times 100 / \mathrm{TOC}_{(\mathrm{i})} \\
& \text { MFOOC }_{f c}=\left(\mathrm{OOC}_{(\mathrm{i})}-\mathrm{OOC}_{(\mathrm{f})}\right) \times 100 / \mathrm{OOC}_{(\mathrm{i})} \\
& \operatorname{MFON}_{f c}=\left(\mathrm{ON}_{(\mathrm{i})}-\mathrm{ON}_{(\mathrm{f})}\right) \times 100 / \mathrm{ON}_{(\mathrm{i})}
\end{aligned}
$$

where,

MFTOC $_{f c}$ - organic carbon mineralization rate based on sludge $\operatorname{TOC}_{(\mathrm{i})}(\%)$;

TOC $_{(\mathrm{i})}$ - sludge total organic carbon thereupon disposal $\left(\right.$ dag $\left.\mathrm{kg}^{-1}\right)$;

TOC $_{(\mathrm{f})}$ - sludge total organic carbon after 131-day disposal (dag kg-1);

MFOOC $_{f c}$ - organic carbon mineralization rate based on sludge $\mathrm{OOC}_{(\mathrm{i})}(\%)$;

OOC $_{(\mathrm{i})}$ - sludge oxidizable carbon thereupon disposal $\left(\right.$ dag kg $\left.^{-1}\right)$;

$\mathrm{OOC}_{(\mathrm{f})}$ - sludge oxidizable carbon after 131-day disposal $\left(\right.$ dag $\left.\mathrm{kg}^{-1}\right)$;

$\mathrm{MFON}_{f c}$ - organic nitrogen mineralization rate based on sludge ON (\%);

$\mathrm{ON}_{(\mathrm{i})}$ - sludge organic nitrogen thereupon disposal $\left(\mathrm{dag} \mathrm{kg}^{-1}\right)$,

$\mathrm{ON}_{(\mathrm{f})}$ - sludge organic nitrogen after 131-day disposal $\left(\right.$ dag $\left.\mathrm{kg}^{-1}\right)$. 
The amounts of TOC, OOC, and ON from incorporation treatment samples were estimated by subtracting the values of these variables in control from the concentrations quantified in samples. This procedure was made because the samples from that treatment had a mix of soil and residue. Differently to the surface laying, this procedure was not performed for the first samples $(0,14$ and 25 days); however, the procedure was resumed for samples from 66, 99 and 131 days after residue application. That can be explained because, unlike the first samples where sludge was superficially disposed, only the organic residue was collected with degrading organic material and a thinner sludge layer; so when collecting material from the pot, a mixture of soil and organic material was withdraw.

After calculating the organic $\mathrm{C}$ and $\mathrm{N}$ mineralization fractions, under field conditions $\left(\mathrm{MF}_{f c}\right)$, the means were compared by the Tukey's test at 5\% significance level using the Sigma Plot software v.12.0.

\section{RESULTS AND DISCUSSION}

The composting process significantly reduced the amount of TN comparing the undigested sludge with the composted material. It was already expected since sludge $\mathrm{pH}$ increased because of organic material mineralization. Therefore, the greater $\mathrm{C} / \mathrm{N}$ ratio found for compost results from such major TN concentration, however, being mostly influenced by lower concentrations of TOC in this material. Once the solid compost layer, applied superficially, has faded away, from where only soil was sampled, experiment monitoring lasted solely 131 days.

Figures 1, 2 and 3 show the concentrations of TOC, OOC and ON of both incorporated and surface applied material throughout the monitoring period.

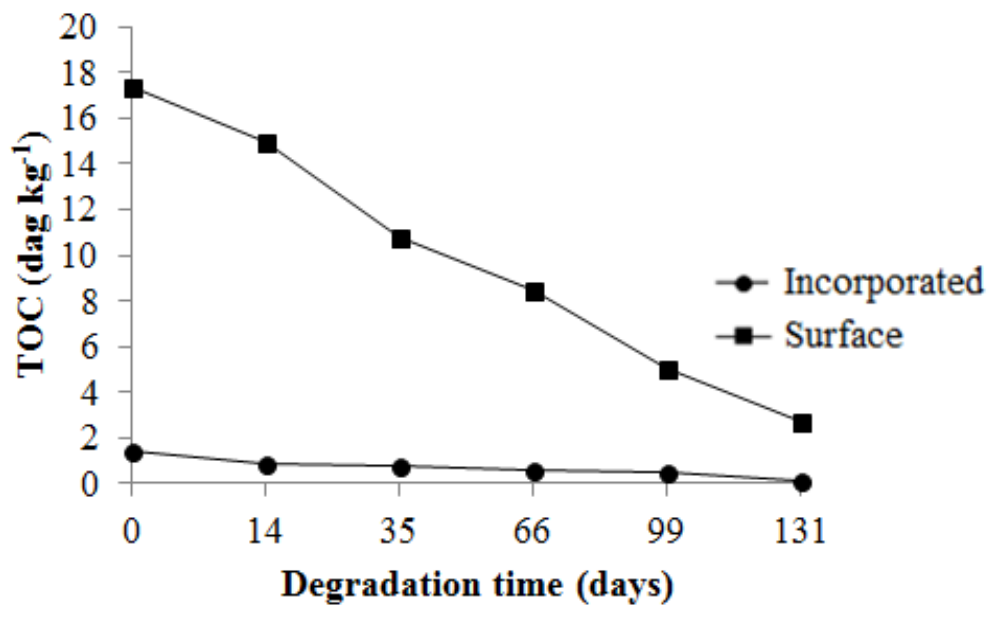

Obs.: dag kg ${ }^{-1}$ is the same as $\%$

FIGURE 1. Contents of total organic carbon (TOC) in incorporated and surface laid compost as function of monitoring time. 


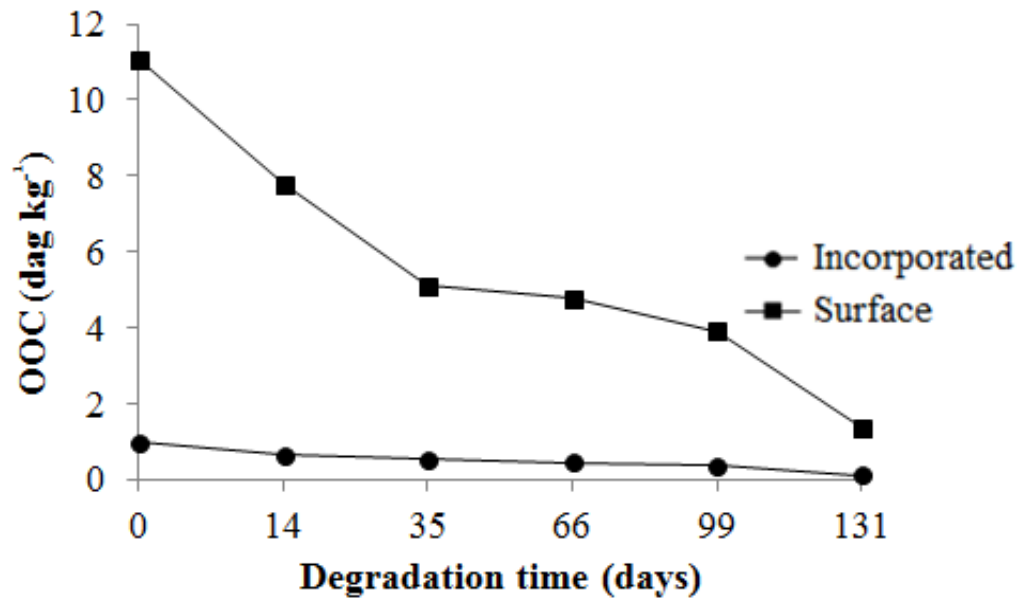

Obs.: dag $\mathrm{kg}^{-1}$ is the same as $\%$

FIGURE 2. Contents of oxidizable carbon (OOC) in incorporated and surface laid compost as function of monitoring time.

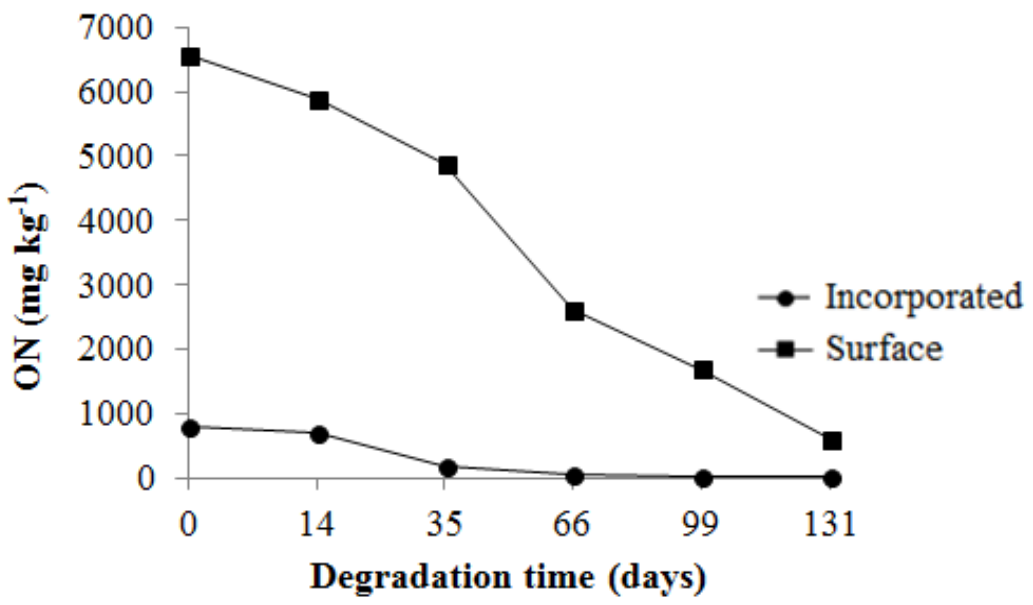

Obs.: dag $\mathrm{kg}^{-1}$ is the same as $\%$

FIGURE 3. Contents of organic nitrogen $(\mathrm{ON})$ in incorporated and surface laid compost as function of monitoring time.

As expected, graphs show decreasing concentrations of TOC, OOC and $\mathrm{ON}$ throughout monitoring, regardless of the application form, however, being most evident for when incorporated to the soil. Thus, it becomes clear that application form was prevailing with respect to the differences among TOC, OOC and ON amounts; accordingly, within the same period, incorporated compost did not mineralized at the same path as the one laid on the soil surface. Residue incorporation sped up substantially organic material degradation. In fact, incorporation benefits might come from several factors, for instance increasing contact between compost particles and soil by intense mixing and homogenizing, maintenance of higher moisture levels for longer time inside pots compared to soil surface, and lack of direct solar radiation that is harmful to degrading microorganisms.

Furthermore, mineralization rates were higher on the first 40 days, with no major differences thenceforth. PAULA et al. (2013) and PEREIRA et al. (2015) also assessed incorporated and surface laid organic residues in field conditions, reporting that the greatest part of OC and ON was mineralized during the first month. Table 4 displays the mineralization rates of TOC, OOC and ON estimated by the equations 1,2 and 3 , above mentioned. 
TABLE 4. Mineralization rates (MF) of TOC, OOC and ON obtained from data settings of mineralized accumulated of TOC, OOC and ON, in soils where the compost was incorporated and surface laid, for a monitoring period of 131 days.

\begin{tabular}{ccccc}
\hline \multirow{2}{*}{ Sludge type } & \multirow{2}{*}{ Application } & MFTOC $_{\boldsymbol{f} \boldsymbol{y}}$ & MFOOC $_{\boldsymbol{c} c}$ & MFON $_{f \boldsymbol{c}}$ \\
\cline { 3 - 5 } & & $\mathbf{( \% )}$ & $\mathbf{( \% )}$ & $\mathbf{( \% )}$ \\
\hline \multirow{2}{*}{ Compost } & Incorporated & $90.0 \mathrm{~A}^{(1)}$ & $87.4 \mathrm{~A}$ & $97.6 \mathrm{~A}$ \\
& Surface laid & $84.2 \mathrm{~B}$ & $87.7 \mathrm{~A}$ & $91.8 \mathrm{~B}$ \\
\hline
\end{tabular}

(1) Means followed by the same letter within the same column do not differ from each other, by the Tukey's test at 5\% significance.

After 131 days of degradation, TOC, OOC and ON mineralization fractions of surface laid composted sludge were of $84.2 \%, 87.7 \%$ and $91.8 \%$, respectively; yet for incorporated sludge, these rates were of $90.0 \%, 87.4 \%$ and $97.6 \%$, respectively.

TOC and ON mineralized rates were statistically different and higher whether the residue was incorporated to the soil. On the other hand, OOC mineralized rates showed no difference between both application methods. ANDRADE et al. (2005), studying kinetics of sewage sludge decomposition which had undergone five different treatments, observed mineralized fractions between 7 to $22 \%$ for a corresponding dose of $40 \mathrm{Mg} \mathrm{ha}^{-1}$. Both previous cited studies were carried out under lab conditions and showed lower values than those found in this study.

MORETTI et al. (2013) analyzed mineralization rates of total $\mathrm{N}$ in a mixture of anaerobically digested sewage sludge and another aerobically digested with addition of urban pruning wastes, under laboratory conditions. These authors observed a rate of $11.7 \%$ for the organic nitrogen after 147 days of incubation, when incorporated into the soil, at a dose of $14.3 \mathrm{Mg} \mathrm{ha}^{-1}$. This value is much lower than those found here, which were $97.6 \%$ and $91.8 \%$ for the incorporated compost and the applied over the soil surface, respectively, at a dose equal to $13.3 \mathrm{Mg} \mathrm{ha}^{-1}$. However, GIACOMINI et al. (2015) obtained respectively $45,3 \%$ and about $60 \%$ of the MFTOC and MFON, after 110 days of the domestic sludge incubation in a sandy soil. PEREIRA et al. (2015) found values of mineralization fractions of OOC and ON, for peach palm residue, of 93.5 and $95.3 \%$, when it was incorporated into the soil; and 59.8 and $62.7 \%$, when disposed on soil surface, respectively, for 102 days of monitoring.

The mineralization fraction, when obtained under field conditions, subjected the residues to contact with larger volume of soil, as being an open system, free flow of solutes between the mediums and waste-environment interactions are most intense, also enabling soil meso-organisms (insects, arthropods etc.) to play a role in decomposition. Besides the action of climatic conditions on the process, such as rainfall and solar radiation.

In addition, it was verified that after 131 days mineralization rates were over $87.4 \%$, irrespective of the variable assessed (TOC, OOC and ON) or for any waste application form. Also, the results run counter recommendation made by CONAMA Resolution $n^{\circ} 375 / 2006$, which states a rate of $10 \%$ for composted sludge, regardless disposal manner. Based on that, estimating the mineralized rates of organic residues at field conditions is clearly important once lab studies do not generate actual rates.

\section{CONCLUSIONS}

Composting promoted significant losses of total nitrogen.

TOC, OOC and ON contents decreased during monitoring, regardless the way compost was applied to the soil, however, being most marked for incorporation.

TOC and ON mineralization rates were statistically different regardless application method, but being higher whether incorporated.

OOC mineralization rates were similar for both application methods. 
It is advised to raise the mineralization rate recommended by the CONAMA Resolution no. $375 / 2006$ for sewage sludge compost to about $87 \%$, independently of the way the waste is disposed to the soil.

\section{REFERENCES}

ALVARENGA, P.; MOURINHA, C.; FARTO, M.; SANTOS, T.; PALMA, P.; SENGO, J.; MORAIS, M. C.; CUNHA-QUEDA, C. Sewage sludge, compost and other representative organic wastes as agricultural soil amendments: Benefits versus limiting factors. Waste Management, New York, v.40, n.3, p.44-52, 2015.

ANDRADE, C.A., OLIVEIRA C., CERRI, C.C. Qualidade da matéria orgânica e estoques de carbono e nitrogênio em Latossolo tratado com biossólido e cultivado com eucalipto. Revista Brasileira de Ciência do Solo, Viçosa, MG, v.29, n.5, p.803-816, 2005.

FERRER, A.; MOCHÓN, I.; OÑA, J.; OSORIO, F. Evolution of the soil and vegetation cover on road embankments after the application of sewage sludge. Water, Air and Soil Pollution, Dordrecht, v.214, p.231-240, 2011.

GIACOMINI, S.J.; SIMON, V.L.G.; AITA, C.; BASTOS, L.M.; WEILER, D.A.; REDIN, M. Carbon and nitrogen mineralization In soil combining sewage sludge and straw. Revista Brasileira de Ciência do Solo, Viçosa, MG, v.39, n.5, p.1428-1435, 2015.

GODOY, L.C. A logística na destinação do lodo de esgoto. Revista Científica On-line Tecnologia - Gestão - Humanismo, Guaratinguetá, v.2, n.1, p.79-90, nov. 2013.

HECK, K.; DE MARCO, E.G.; HAHN, A.B.B.; KLUGE, M.; SPILKI, F.R.; VAN DER SAND, S.T. Temperatura de degradação de resíduos em processo de compostagem e qualidade microbiológica do composto final. Revista Brasileira de Engenharia Agrícola e Ambiental, Campina Grande, v.17, n.1, p.54-59, 2013.

KUMMER, A.C.B. Efeito de efluente de esgoto tratado e lodo de esgoto compostado no solo e nas culturas de trigo e soja. Botucatu. 2013. 194f. Tese (Doutorado em Irrigação e Drenagem) Faculdade de Ciências Agronômicas, Universidade Estadual Paulista. Botucatu, 2013.

MATOS, A.T. Manual de análise de resíduos sólidos e águas residuárias. Viçosa: Imprensa Universitária, UFV. 2015. 149p.

MORETTI, S.M.L.; BERTONCINI, E.I.; ABREU-JUNIOR, C.H. Aplicação do método de mineralização de nitrogênio com lixiviação para solo tratado com lodo de esgoto e composto orgânico. Revista Brasileira de Ciência do Solo, Viçosa, MG, v.37, p.622-631, 2013.

NASCIMENTO, A.L.; SAMPAIO, R.A.; CRUZ, S.F. ; JUNIO, G.R.Z.; BARBOSA, C.F.; FERNANDES, L.A. Metais pesados em girassol adubado com lodo de esgoto submetido a diferentes processos de estabilização. Revista Brasileira de Engenharia Agrícola e Ambiental, Campina Grande, v.18, n.7, p. 694-699, 2014.

PAULA, J.R.; MATOS, A.T.; MATOS, M.P.; PEREIRA, M.S.; ANDRADE, C.A. Mineralização do carbono e nitrogênio de resíduos aplicados ao solo em campo. Revista Brasileira de Engenharia Agrícola e Ambiental, Campina Grande, v.37, p.1729-1741, 2013.

PEREIRA, M.S.; MATOS, A.T.; BORGES, A.C.; NUNES, M.F. Mineralização do resíduo da pupunheira em condições de campo e laboratório. Engenharia Agrícola, Jaboticabal, v.35, n.5, p.918-930, set./out. 2015.

SINGH, R.P.; AGRAWAL, M. Potential benefits and risks of land application of sewage sludge. Waste Management, New York, v.28, n.2, p.347-358, 2008. 